\title{
Protein S as an In Vivo Cofactor to Activated Protein C in Prevention of Microarterial Thrombosis in Rabbits
}

\author{
Björn Amljots *‡ and Björn Dahlbäck \\ Departments of * Plastic and Reconstructive Surgery, ${ }^{\ddagger}$ Experimental Research, and ${ }^{\S}$ Clinical Chemistry, University of Lund, \\ Malmö General Hospital, S-214 01 Malmö, Sweden
}

\begin{abstract}
The antithrombotic effects of bovine activated protein $\mathrm{C}$ (APC) and protein $S$ were investigated in a rabbit model of microarterial thrombosis. Because of the species specificity of the APC-protein S interaction, bovine APC expresses potent anticoagulant activity in rabbit plasma only when bovine protein $S$ is also present. This provided a way to assess the contribution of bovine protein $S$ to the antithrombotic effect of bovine APC. Rabbits were infused with boluses of activated protein $\mathrm{C}(0.1,0.2,0.4$, or $0.8 \mathrm{mg} / \mathrm{kg})$, protein $S(0.5 \mathrm{mg} / \mathrm{kg})$, or activated protein $\mathrm{C}(0.1$ or 0.01 $\mathrm{mg} / \mathrm{kg})$ plus protein $\mathrm{S}(0.5 \mathrm{mg} / \mathrm{kg})$. APC alone produced a dose-dependent antithrombotic effect, but only the group receiving the highest dose differed significantly from controls. While a low dose of activated protein $\mathrm{C}(0.1 \mathrm{mg} / \mathrm{kg})$ alone had no antithrombotic effect, together with protein $S$ $(0.5 \mathrm{mg} / \mathrm{kg})$ it produced a potent response. The presented results demonstrate the in vivo significance of protein $S$ as a cofactor to activated protein $\mathrm{C}$. The data show that a potent antithrombotic effect, without hemorrhagic side effects or significant systemic anticoagulation, may be achieved by low doses of activated protein $\mathrm{C}$ when combined with protein S. (J. Clin. Invest. 1995. 95:1987-1993.) Key words: protein $\mathrm{C} \cdot$ protein $\mathrm{S} \cdot$ thrombosis $\cdot$ animal model
\end{abstract}

\section{Introduction}

The self-amplifying cascade of blood coagulation constitutes a potential danger to the organism, and several control systems are operative to dampen its actions. One of these systems is the protein $\mathrm{C}$ anticoagulant system, which provides a powerful mechanism for limitation of thrombus formation and propagation in vivo (reviewed in 1). The key components of the protein $\mathrm{C}$ anticoagulant system are the vitamin $\mathrm{K}$-dependent proteins $\mathrm{C}$ and $\mathrm{S}$ and the endothelial cell membrane protein thrombomo-

Address correspondence to Björn Arnljots, Department of Plastic and Reconstructive Surgery, Malmö General Hospital, S-214 01 Malmö, Sweden. Phone: 40-331000; FAX: 40-336271.

Received for publication 13 September 1994 and in revised form 22 December 1994.

1. Abbreviations used in this paper: APC, activated protein C; APTT, activated partial thromboplastin time; C4BP, C4b-binding protein; EU, endotoxin units; TBS, Tris-buffered saline.

J. Clin. Invest.

(C) The American Society for Clinical Investigation, Inc.

0021-9738/95/05/1987/07 $\$ 2.00$

Volume 95, May 1995, 1987-1993 dulin. Protein $\mathrm{C}$ circulates as zymogen of a serine protease and is converted to its active form by thrombin bound to thrombomodulin. Activated protein C (APC) ${ }^{1}$ selectively degrades the activated forms of coagulation cofactors V and VIII, thereby counteracting the positive feedback actions of thrombin on the coagulation cascade. This process is potentiated by the vitamin $\mathrm{K}$-dependent protein $\mathrm{S}$. In human plasma, protein $\mathrm{S}$ forms a complex with C4b-binding protein (C4BP), which is a regulator of the classical complement pathway (reviewed in 1,2 ). Only free protein $\mathrm{S}$ acts as a cofactor to APC, whereas the complexed form, which accounts for $\sim 60 \%$ of total protein $S$ in human plasma, has no anticoagulant cofactor activity (3-5). Rabbit plasma only contains free protein $S$, which, however, is readily complexed with human C4BP $(6,7)$. Recently, another cofactor to APC was proposed (8) and subsequently identified as the nonactivated form of Factor $\mathrm{V}(9,10)$. The biological significance of the endogenous anticoagulant protein $C$ system is best illustrated by the massive neonatal thrombotic events that accompany homozygous deficiency of either protein $\mathrm{C}$ or protein $S$ (11) and the milder thrombophilia that is associated with heterozygous deficiencies (12). Moreover, it has recently been shown that resistance to the anticoagulant function of APC, due to a single point mutation in the gene for Factor $\mathrm{V}$, is a major risk factor for thrombosis $(8,9,13-20)$.

Because of its specific anticoagulant activity and its endogenous origin, APC is potentially highly interesting as an antithrombotic agent. The antithrombotic features of APC have been demonstrated in different animal studies. Thus, human APC blocks the lethal effects of Escherichia coli endotoxin shock in baboons (21), reduces jugular vein thrombus formation in dogs (22), delays anodal current-induced aorta thrombus formation in rats (23), and reduces intermittent platelet thrombus formation in rat microvessels (24). Human APC is also an effective antithrombotic agent in a hypertraumatic arteriovenous graft model in baboons, when infused in close proximity to the trauma area $(25,26)$. An antithrombotic effect of thrombin-generated endogenous APC has also been demonstrated in the same model (27). Using bovine material, Emekli et al. demonstrated in an early study that APC blocks disseminated intravascular coagulation in rabbits (28). Recently, we have shown that a high intravenous bolus of bovine APC effectively prevents thrombosis in a highly traumatic microarterial model in rabbits (29).

Although previous work has demonstrated the importance of protein $S$ in tuning down combined inflammatory and coagulopathic responses in states of experimental $E$. coli-induced disseminated intravascular coagulation (30), the in vivo role of protein $S$ as a cofactor to APC is essentially unknown. In fact, the importance of the APC cofactor function of protein S has been debated, because the cofactor activity is quite weak in in vitro systems, and, in addition, it has been suggested that 
protein $S$ also has anticoagulant properties independent of APC (31-33). Protein $S$ increases the proteolytic activity of APC twofold, and, in addition, it inhibits the protection of Factors VIIIa and Va against APC-mediated degradation that Factors IXa and Xa, respectively, provide $(32,34)$. Protein $S$ is known to increase the affinity of APC for negatively charged phospholipids where enzyme and cofactor seem to form a 1:1 stoichiometric complex $(35,36)$. Since thrombus formation is a process largely taking place on activated membrane surfaces, a key function of protein $S$ in vivo may be to target APC to sites of evolving thrombi.

The APC cofactor function of protein $\mathrm{S}$ is species specific (37), which provides an experimental tool for specifically studying the importance of protein $S$ in vivo. The present study was undertaken to characterize the antithrombotic potential of APC and protein $S$ in a rabbit model of microarterial thrombosis, using bovine protein components. We report that APC has an antithrombotic effect in this animal model and that the APC cofactor activity of protein $\mathrm{S}$ is important in vivo for expression of full antithrombotic activity of APC.

\section{Methods}

Thrombosis model. Swedish loop rabbits of either sex, weighing 2.5$3.5 \mathrm{~kg}$ (mean $3.0 \mathrm{~kg}$ ), were anesthetized with intravenous pentobarbital. A detailed description of the experimental procedure has been given elsewhere (29). Briefly, 3-cm-long segments of the central arteries of both ears (outer diameter $\sim 1 \mathrm{~mm}$ ) were prepared. Blood flow was interrupted, and 7-mm artery segments were isolated between vascular clamps. 7-mm-long arteriotomies were performed, vascular lumina were everted and flattened, and $5 \mathrm{~mm}$ of vascular lumina was denuded with a scalpel blade, thereby exposing deep layers of the tunica media (38). The arteriotomies were closed with continuous sutures. After reperfusion (opening of the vascular clamps), arteriotomy bleeding times were recorded. Vessel patency was assessed at 30 and $120 \mathrm{~min}$ after reperfusion using a standard microsurgical empty/refill test $(29,39)$. In this test, the vessels were occluded distal to the trauma area using a pair of microforceps and gently emptied downstream with another pair of forceps. The first pair of forceps was then released, and the vessel refilling was assessed, classing the vessels as patent or occluded. Occluded vessels showed no refilling, while patent vessels showed rapid or slow refilling, the latter being referred to as "reduced patency." After the final patency test, the thrombotic material was removed and weighed. The animals were killed by injection of concentrated sodium pentobarbital and alcohol.

Proteins. Bovine protein $\mathrm{C}$ was purified and activated as described previously $(29,40)$. The protein was $>95 \%$ pure, as judged by PAGE run in the presence of SDS before and after reduction of disulphide bonds. In the presence of bovine protein S, bovine APC $(0.5-1 \mu \mathrm{g} /$ $\mathrm{ml}$ ) prolonged the activated partial thromboplastin time (APTT) of human plasma two- to threefold (29). In the absence of bovine protein $S$, bovine APC had little effect on the clotting of human plasma, which is in agreement with results on record (37). The effects of bovine APC, with and without added bovine protein $S$, in a rabbit plasma system have been previously shown $(6,29)$. Bovine protein $S$ and human C4BP (devoid of protein $S$ ) were purified as described previously $(41,42)$. The endotoxin levels of the protein preparations, measured with a commercial endotoxin kit (Coatest Endotoxin; Chromogenix, Mölndal, Sweden) were 150-200 endotoxin units (EU) per mg of APC, $632 \mathrm{EU}$ per $\mathrm{mg}$ of protein S, and $360 \mathrm{EU}$ per $\mathrm{mg}$ of C4BP (1 EU $\sim 10 \mathrm{pg}$ ).

Experimental protocol. 11 groups of rabbits were treated as follows. In a dose-response study, four groups were treated with $0.1,0.2,0.4$, or $0.8 \mathrm{mg} / \mathrm{kg}$ body weight of APC in Tris-buffered saline (TBS) supplemented with BSA, whereas one group received vehicle only $(50 \mathrm{mM}$
Tris- $\mathrm{HCl}, 0.15 \mathrm{M} \mathrm{NaCl}$, $\mathrm{pH} 7.5$, containing $1 \mathrm{mg} / \mathrm{ml} \mathrm{BSA}$ ). A separate group of rabbits receiving $0.8 \mathrm{mg} / \mathrm{kg}$ APC were given boluses of human C4BP $(4 \mathrm{mg} / \mathrm{kg}) 15 \mathrm{~min}$ before administration of APC. In a subsequent study (referred to as the protein $S$ study), five groups of rabbits were treated with either $0.1 \mathrm{mg} / \mathrm{kg} \mathrm{APC}, 0.5 \mathrm{mg} / \mathrm{kg}$ protein $\mathrm{S}, 0.1 \mathrm{mg} / \mathrm{kg}$ $\mathrm{APC}+0.5 \mathrm{mg} / \mathrm{kg}$ protein $\mathrm{S}, 0.01 \mathrm{mg} / \mathrm{kg} \mathrm{APC}+0.5 \mathrm{mg} / \mathrm{kg}$ protein $\mathrm{S}$, or vehicle. The number of rabbits in each experimental group was 10 , and, since both ears were used in each rabbit, data from 20 vessels were obtained in each group, except for the vehicle and $0.8 \mathrm{mg} / \mathrm{kg} \mathrm{APC}$ groups in the dose-response study and the $0.1 \mathrm{mg} / \mathrm{kg}$ APC group in the protein S study, where the number of observations was 19 for technical reasons. Throughout, the animals were treated in a blind random fashion, except for the C4BP group in the dose-response study, which was added as a separate group after completion of the randomized series. APC, protein $\mathrm{S}$, or their combinations were given as intravenous bolus injections $5 \mathrm{~min}$ before vascular reperfusion. Different batches of APC were used in the dose-response study and in the protein S study.

Plasma levels of infused proteins. The levels of infused bovine APC and protein $S$ in rabbit plasma were assessed with ELISA assays, using citrated plasma sampled as described above. Microtiter plates (Linbro E.I.A. microtitration plates; Flow Laboratories, Irvine, UK) were coated overnight at $4^{\circ} \mathrm{C}$ with rabbit polyclonal antibodies raised against either bovine protein $\mathrm{C}$ or protein $\mathrm{S}(10 \mu \mathrm{g} / \mathrm{ml}$ of immunoglobulin fraction

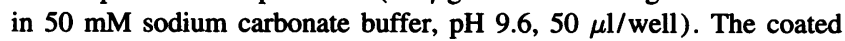
wells were quenched for $1 \mathrm{~h}$ at room temperature with $200 \mu \mathrm{l}$ of $1 \%$ BSA in TBS and then washed three times with TBS containing $0.1 \%$ Tween-20. Rabbit plasma was serially diluted in TBS containing $0.1 \%$ BSA, $2 \mathrm{mM} \mathrm{CaCl}_{2}$, and $0.1 \mu \mathrm{M}$ of $d$-phenylalanyl- $l$-prolyl- $l$-arginine chloromethylketone (PPACK; Calbiochem-Novabiochem Corp., La Jolla, CA). The diluted samples ( $40 \mu \mathrm{l} /$ well) were incubated overnight at $4^{\circ} \mathrm{C}$, after which the wells were washed three times. Mouse monoclonal antibodies against bovine protein C (BPC 5) (a kind gift from Professor Johan Stenflo, Dept. of Clinical Chemistry, Malmö General Hospital, Malmö, Sweden) or against protein S (HPS 21) (43) (4 or $10 \mu \mathrm{g} / \mathrm{ml}$, respectively, in TBS containing $0.1 \%$ BSA and $2 \mathrm{mM} \mathrm{CaCl}$, $50 \mu \mathrm{l} /$ well) were incubated at room temperature for $2 \mathrm{~h}$, after which the wells were washed three times. Rabbit peroxidase-conjugated antimouse antibodies (DAKO; Dakopatts A/S, Glostrup, Denmark) (diluted $1 / 1,000$ in TBS, $0.1 \% \mathrm{BSA}, 2 \mathrm{mM} \mathrm{CaCl}, 50 \mu \mathrm{l} /$ well) were added, and the plates were incubated for $1 \mathrm{~h}$, after which the wells were washed three times. $200 \mu \mathrm{l}$ of the substrate $2,2^{\prime}$-azino-bis(3ethylbenzthiazoline-6-sulfuronic acid) (ABTS; Sigma Chemical Co., St. Louis, MO) was added to each well and the absorbance was measured at $405 \mathrm{~nm}$.

Estimates of endogenous (rabbit) levels of proteins $C$ and $S$. Rabbit protein $\mathrm{C}$ plasma concentration was estimated using a commercial kit for detection of protein $\mathbf{C}$ activity in human plasma (Coamatic Protein $\mathrm{C}$; Chromogenix). The assay involves activation of protein $\mathrm{C}$ by snake venom and determination of the rate of hydrolysis of the chromogenic substrate S-2366 measured at $\mathbf{4 0 5} \mathrm{nm}$ in an automatic analyzer (Cobas Mira, Roche, Basel, Switzerland). A dilution curve obtained with citrated rabbit plasma (sampled as above) was closely parallel to the standard curve for human plasma, and therefore rabbit plasma samples were read against the human standard curve. Rabbit protein $S$ levels were estimated by a clotting assay that measured inhibition of human APC cofactor function in rabbit plasma by human C4BP and was performed essentially as described elsewhere (6). Increasing amounts of purified human C4BP were added to rabbit plasma ( final concentrations $0-200 \mu \mathrm{g} / \mathrm{ml}$ ) and incubated for $2 \mathrm{~h}$ at $37^{\circ} \mathrm{C}$. The rabbit plasma (100 $\mu \mathrm{l})$ was then incubated with $100 \mu \mathrm{l}$ of APTT reagent (PTT automate; Diagnostica Stago, Asnières, France) for $5 \mathrm{~min}$ at $37^{\circ} \mathrm{C}$, after which $100 \mu \mathrm{l}$ of $30 \mathrm{mM}$ calcium chloride containing human APC (final concentration $0.5 \mu \mathrm{g} / \mathrm{ml}$ ) was added and the clotting time measured with an Amelung Coagulometer KC 10 (Heinrich Amelung GmbH, Lieme, Germany). The molar concentration of protein $S$ in rabbit plasma was assumed to be equal to the lowest concentration of C4BP that still gave full inhibition of APC cofactor function. 


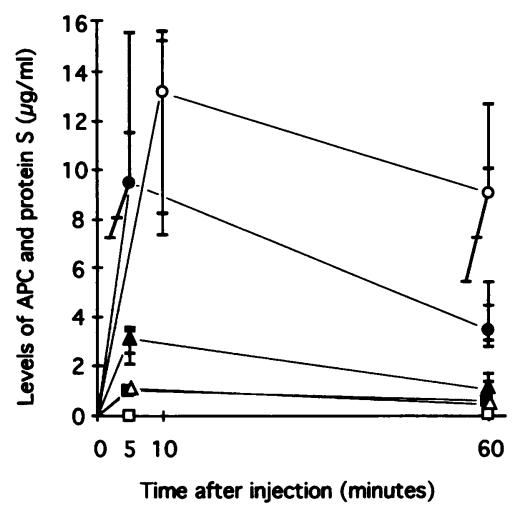

Values at 5 and 60 min after injection are shown, since, in pilot analyses of APC levels during the 120-min observation interval, the 5-min values were found to represent the peak concentrations and there was little decrease in values in the 60-120-min interval (data not shown). Protein $\mathrm{S}$ levels exceeded the APC levels and were more sustained in time, also in the interval 60-120 min after infusion (data not shown). (O)

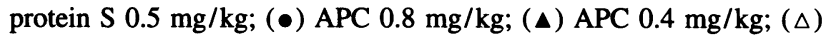
APC $0.2 \mathrm{mg} / \mathrm{kg}$; (घ) APC $0.1 \mathrm{mg} / \mathrm{kg}$; () APC $0.01 \mathrm{mg} / \mathrm{kg} ; n=10$ for all doses. 50th percentiles are plotted, and 10th, 25th, 75th, and 90th percentiles (error bars) are given for selected groups.

Hemostatic parameters. Analyses of APTT and platelet counts were performed essentially as described (29). Blood for APTT analyses was drawn just before and at 10,60 , and $120 \mathrm{~min}$ after administration of the substances. In animals pretreated with $\mathrm{C} 4 \mathrm{BP}$, samples were also drawn after the administration of C4BP but immediately before infusion of APC. The samples (nine parts blood, one part $3.85 \%$ sodium citrate) were centrifuged for $15 \mathrm{~min}$ at $5,000 \mathrm{rpm}$ and frozen directly at $-70^{\circ} \mathrm{C}$. APTT was analyzed immediately after thawing. Blood samples for platelet counts were drawn just before and $60 \mathrm{~min}$ after APC administration (in animals pretreated with $\mathrm{C} 4 \mathrm{BP}$, preinfusion samples were drawn before the infusion of C4BP, and postinfusion samples $75 \mathrm{~min}$ later). Platelets were counted in Technicon H1 (Technicon Instrument, Tarrytown, NY) or STKS automatic analyzers (Coulter Corp., Hialeah, FL) or in a minority of cases in a Bürker's chamber (Poly-Optik GmbH, Bad Blankenburg, Germany).

Statistical methods. StatXact (CYTEL Software Corporation; Cambridge, MA) was used for statistical calculations. Pairwise observations were obtained from each animal, and statistical comparisons were therefore based on the assumption that the observations were interdependent. Mean values for arteriotomy bleeding times and thrombus weights were calculated for each animal, and groups were compared using the MannWhitney $U$ test. Patency in each animal was coded as 0,1 , or 2 depending on the number of patent vessels, and the Jonckheere-Terpstra test (44) was used for comparison between the groups. Two-sided $P$ values are given, and medians and percentiles are shown. $P$ values $<0.05$ were regarded as statistically significant.

\section{Results}

Plasma levels of endogenous and infused proteins. Using a chromogenic functional assay, the concentration of protein $\mathrm{C}$ in rabbit plasma was estimated to be $\sim 80 \%$ (mean of 10 observations) of that of protein $\mathrm{C}$ in human plasma $(3-5 \mu \mathrm{g} / \mathrm{ml})$. The concentration of protein $S$ in rabbit plasma was estimated from the ability of human C4BP to dose-dependently inhibit the APC cofactor function in rabbit plasma. The APC cofactor function was lost at a C4BP concentration of $20 \mu \mathrm{g} / \mathrm{ml}$, which suggests the protein $\mathrm{S}$ level in rabbit plasma to be $\sim 3 \mu \mathrm{g} / \mathrm{ml}$.
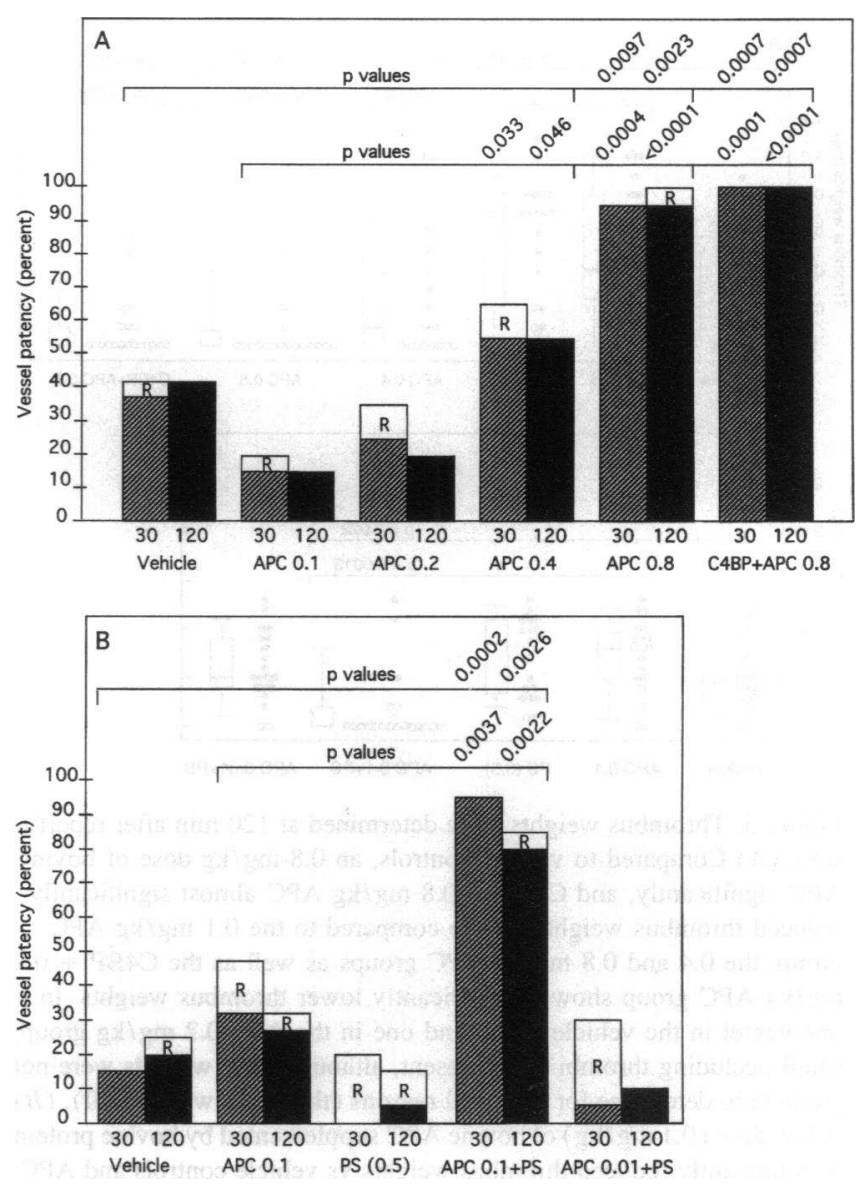

Figure 2. Vessel patency was determined at 30 and 120 min after reperfusion. ( $A$ ) A high dose of bovine APC $(0.8 \mathrm{mg} / \mathrm{kg})$ significantly increased patency rates vs controls. Preadministration of human C4BP in a dose sufficient to complex all rabbit protein $S$ did not alter the patency rate produced by this APC dose. When compared to the 0.1 $\mathrm{mg} / \mathrm{kg}$ APC dose, both 0.4 and $0.8 \mathrm{mg} / \mathrm{kg}$ of APC significantly improved patency rates $(n=19$ in the vehicle and APC $0.8 \mathrm{mg}$ groups, otherwise $n=20$ ). (B) A low dose $(0.1 \mathrm{mg} / \mathrm{kg}$ ) of bovine APC supplemented by bovine protein $S$ produced a powerful antithrombotic response, comparable to the $0.8 \mathrm{mg} / \mathrm{kg}$ APC dose $(n=19$ in the APC $0.1 \mathrm{mg}$ group, otherwise $n=20$ ). Significant differences are shown with $P$ values. $P S$, protein $\mathrm{S} ; R$, reduced patency.

This is distinctly lower than the concentration of free protein $\mathrm{S}$ in human plasma $(10 \mu \mathrm{g} / \mathrm{ml})$. The highest bolus $(0.8 \mathrm{mg} / \mathrm{kg})$ of bovine APC gave median concentrations in rabbit plasma of $9.5 \mu \mathrm{g} / \mathrm{ml}$ (Fig. 1), which was more than three times the endogenous protein $C$ concentration. The $0.4-\mathrm{mg} / \mathrm{ml}$ dose produced plasma levels comparable to the physiological protein $\mathrm{C}$ levels, and the $0.1-\mathrm{mg} / \mathrm{kg}$ dose yielded concentrations below the physiological protein $\mathrm{C}$ levels. The plasma concentrations of bovine protein $\mathrm{S}$ after the $0.5-\mathrm{mg} / \mathrm{kg}$ bolus dose peaked at $13.2 \mu \mathrm{g} / \mathrm{ml}$ (median value) and were more sustained in time than the APC levels.

Antithrombotic effects. In the dose-response study, only the highest APC dose $(0.8 \mathrm{mg} / \mathrm{kg})$ produced a powerful antithrombotic effect, which was evident both in assessment of patency rates at 30 and $120 \mathrm{~min}$ after reperfusion (Fig. 2), and in measurements of thrombus weights (Fig. 3). However, a significant 

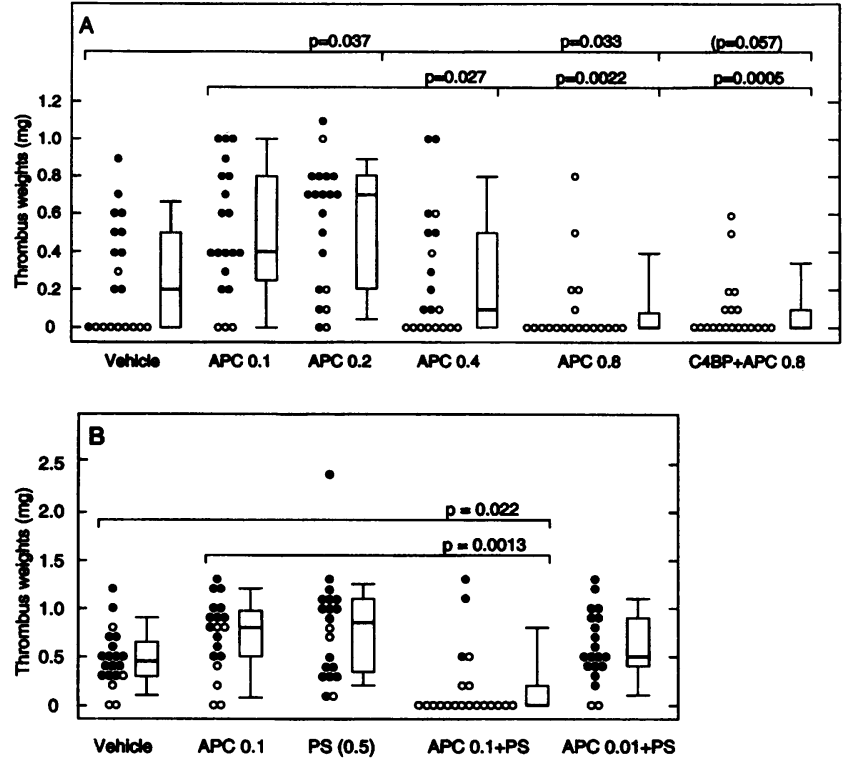

Figure 3. Thrombus weights were determined at $120 \mathrm{~min}$ after reperfusion. $(A)$ Compared to vehicle controls, an $0.8-\mathrm{mg} / \mathrm{kg}$ dose of bovine APC significantly, and C4BP $+0.8 \mathrm{mg} / \mathrm{kg}$ APC almost significantly, reduced thrombus weights. When compared to the $0.1 \mathrm{mg} / \mathrm{kg}$ APC group, the 0.4 and $0.8 \mathrm{mg} / \mathrm{kg}$ APC groups as well as the C4BP +0.8 $\mathrm{mg} / \mathrm{kg}$ APC group showed significantly lower thrombus weights. In one vessel in the vehicle group and one in the APC $0.2 \mathrm{mg} / \mathrm{kg}$ group, small occluding thrombi were present, although their weights were not possible to determine for technical reasons (thrombus weight $=0) .(B)$ A low dose $(0.1 \mathrm{mg} / \mathrm{kg})$ of bovine APC supplemented by bovine protein $S$ significantly reduced thrombus weights vs vehicle controls and APC. Significant differences are shown with $P$ values, as are differences close to statistical significance (parentheses). Boxes include 25th, 50th (fat line), and 75th percentiles, and bars show 10th and 90th percentiles. Filled circles indicate occluded vessels. $P S$, protein $\mathrm{S}$.

dose-dependent antithrombotic response was observed when comparison was made between the three APC groups. Pretreatment of rabbits with a dose of human C4BP, which was high enough to complex all rabbit protein $S(6)$, did not inhibit the effect of the high dose of APC, although thrombus weights in the group receiving C4BP and $0.8 \mathrm{mg} / \mathrm{kg}$ of APC were slightly higher than those found in the group treated with APC alone. In the protein S study, the $0.1-\mathrm{mg} / \mathrm{kg}$ dose of APC gave drastically improved vessel patency rates and significant reduction of thrombus weights, but only when APC was given together with protein S. The effect of APC $(0.1 \mathrm{mg} / \mathrm{kg})$ plus protein $S(0.5$ $\mathrm{mg} / \mathrm{kg}$ ) was comparable to that produced by $0.8 \mathrm{mg} / \mathrm{kg}$ of APC alone. The antithrombotic effect of the APC-protein S combination was lost upon reduction of the APC dose to 0.01 $\mathrm{mg} / \mathrm{kg}$. Protein $\mathrm{S}$ in itself did not affect the antithrombotic score.

Antihemostatic effects. The highest dose of APC produced a mild hemostatic defect, as detected by prolonged bleeding times, and a significant dose-dependent effect was observed when comparison was made between the three APC groups (Fig. 4). In the protein S study, no significant effects on hemostasis were noted by the combination of $\operatorname{APC}(0.1 \mathrm{mg} / \mathrm{kg})$ and protein $\mathrm{S}$.

Anticoagulant effects. Whereas the lower doses of APC
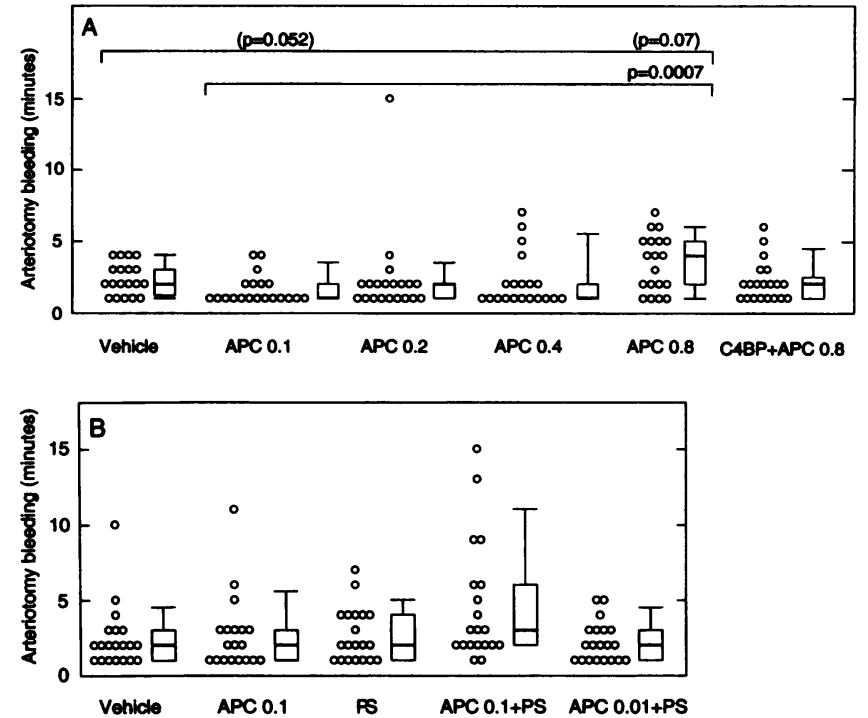

Figure 4. Arteriotomy bleeding times were assessed as vascular clamps were released. (A) A $0.8-\mathrm{mg} / \mathrm{kg}$ dose of bovine APC produced a mild hemostatic defect; the difference vs the APC $0.1 \mathrm{mg}$ group was significant and showed a strong trend towards statistical significance when compared to vehicle controls. $(B)$ A $0.1-\mathrm{mg} / \mathrm{kg}$ dose of bovine APC supplemented by bovine protein $S$ did not produce hemorrhagic side effects. Abbreviations and statistical presentation are as in Fig. 3.

(0.1 $-0.4 \mathrm{mg} / \mathrm{kg})$ did not yield any measurable effect, or only modestly prolonged the APTT, the highest dose $(0.8 \mathrm{mg} / \mathrm{kg})$ produced a distinct APTT prolongation (Fig. 5). Median values of APC-induced APTT prolongation were maximally 2.2 times the baseline at $10 \mathrm{~min}$ after reperfusion. The anticoagulant response in the $0.8-\mathrm{mg} / \mathrm{kg}$ group showed great interindividual variation, in particular shortly after injection. Pretreatment with C4BP resulted in a decrease in the APTT prolongations seen after APC infusion. C4BP alone did not alter the baseline APTT values. In the protein $S$ study, a notable feature was that, in contrast to the potent antithrombotic response produced by APC $(0.1 \mathrm{mg} / \mathrm{kg})+$ protein $\mathrm{S}(0.5 \mathrm{mg} / \mathrm{kg})$, the anticoagulant response was mild, APTT prolongation being maximally 1.3 times the baseline. Protein S alone did not affect the APTT.

Platelet counts. Numbers of circulating platelets remained essentially unchanged in all groups except for the group infused with human C4BP, which showed a distinct drop in platelet count, median platelet count at 75 min after infusion being $57 \%$ of preinfusion values.

\section{Discussion}

This study for the first time shows the significance of protein $S$ as a cofactor to activated protein $C$ in vivo by demonstrating potentiation of the antithrombotic effect of APC in a model of experimental thrombosis. In the model used, the effects of a multitude of antithrombotic agents have been described (4551 ). Since surgical repair of the vessels is involved, hemostatic side effects of given agents may be assessed, as demonstrated by previous studies $(29,49)$.

The APC cofactor function of protein $S$ demonstrates species specificity $(5,37)$. Depending on the experimental condi- 

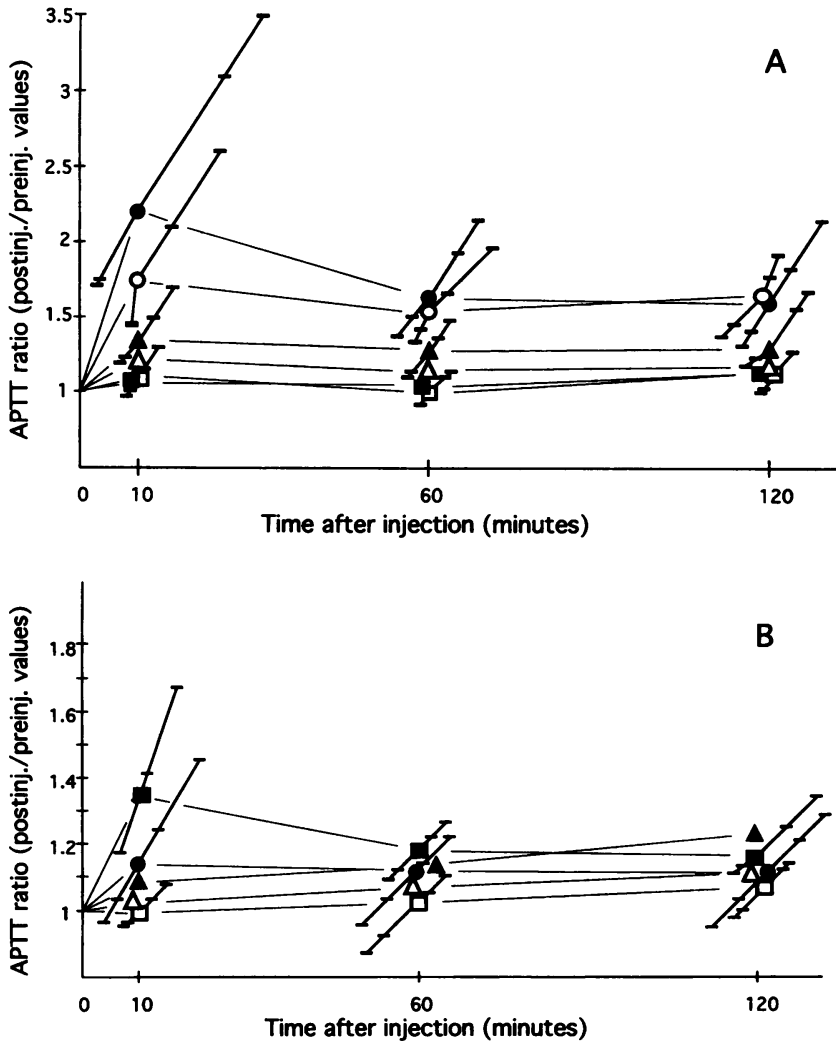

Figure 5. The effect of boluses of bovine APC, protein $\mathrm{S}(0.5 \mathrm{mg} / \mathrm{kg})$, or vehicle on APTT prolongation in rabbit plasma. $(A)$ A $0.8-\mathrm{mg} / \mathrm{kg}$ dose of bovine APC produced a marked prolongation of the clotting time, an effect that was somewhat tuned down initially by pretreating the rabbits with human C4BP in a dose $(4 \mathrm{mg} / \mathrm{kg})$ sufficient to complex all free rabbit protein S. C4BP did not alter baseline APTT values (data

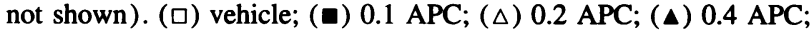
(O) C4BP + 0.8 APC; $(\bullet) 0.8 \mathrm{mg} / \mathrm{kg} \mathrm{APC}$. (B) A $0.1-\mathrm{mg} / \mathrm{kg}$ dose of bovine APC supplemented by bovine protein $S$ resulted in only a mild prolongation of APTT. $(\square)$ vehicle; $(\Delta)$ protein S; ( $\Delta$ ) 0.01 APC + protein $\mathrm{S} ;(\bullet) 0.1 \mathrm{APC} ;(\square) 0.1 \mathrm{mg} / \mathrm{kg} \mathrm{APC}+$ protein $\mathrm{S} ; n=10$ in all groups. Statistical presentation analogous to that given in Fig. 1.

tions, the ability of rabbit protein $\mathrm{S}$ to potentiate the anticoagulant response to bovine APC has been found to be almost nil (37) or relatively low (6). This species specificity provides a basis by which the in vivo effects produced by APC and by APC plus protein $\mathrm{S}$ can be distinguished. The findings of slightly reduced APC-mediated prolongation of the APTT and a minor increase in thrombus weights after pretreatment of the rabbits with $\mathrm{C} 4 \mathrm{BP}$ in the present dose-response study are in agreement with the observation that rabbit protein $S$ potentiates the effects of bovine APC to a certain degree. However, this cofactor effect of rabbit protein $\mathrm{S}$ seems to be marginal, because APC produced a potent antithrombotic effect both when administered alone and when administered together with a great molar excess of C4BP, sufficient to complex all free rabbit protein $S$ (6). This suggested that protein $S$ may not be an obligate prerequisite for the expression of the antithrombotic effect of APC. This is concordant with in vitro anticoagulant findings with human material $(5,32)$. However, the protein $\mathrm{C}$ anticoagulant pathway appears to be more complex than previously described, as it was recently shown that human plasma contains a hitherto unrecognized cofactor to APC (8). This APC cofactor has been identified as Factor V, which in its unactivated state possesses anticoagulant properties functioning in synergy with protein $S(9,10)$. It remains to be elucidated whether rabbit Factor V also expresses such APC cofactor activity and whether it stimulates the anticoagulant effect of bovine APC.

APC produced an antithrombotic effect comparable to recombinant hirudin and clearly superior to unfractionated heparin in this model (51). The net finding supports the conclusion that high doses of bovine APC are needed to produce an antithrombotic effect in arteries under conditions in which the potentiation of the APC effect by protein $S$ is absent or low: The amount of bovine APC needed in this study greatly exceeded the physiological plasma content of protein $\mathrm{C}$, and a significant antithrombotic effect was achieved only at supraphysiologic plasma levels of bovine APC. In contrast, a comparable antithrombotic effect was achieved by a much lower dose of APC when it was supplemented with its species-specific cofactor protein S. Since the APC cofactor function of protein $S$ is weak in in vitro systems $(31,32)$, it has led many investigators to propose the existence of another and possibly a more significant APC cofactor than protein S. Although, as stated above, a second important cofactor has been identified as the nonactivated form of Factor $V$, this study shows that the protein $\mathrm{S}$ cofactor function is of significant importance for the expression of the antithrombotic effect of APC in vivo. Also, these findings confirm earlier in vitro data suggesting the protein $\mathrm{S}$ cofactor function to be species specific.

In contrast to the pronounced antithrombotic and concomitant anticoagulant response produced by $0.8 \mathrm{mg} / \mathrm{kg}$ of APC, the anticoagulant response produced by $0.1 \mathrm{mg} / \mathrm{kg}$ APC plus protein S, which produced an equal antithrombotic score, was remarkably mild. This is entirely compatible with the concept that, through its high affinity for negatively charged phospholipids, a pivotal physiological function of protein $S$ is to target APC to sites of thrombus formation, thus providing a powerful mechanism of local control of coagulation without the expense of a systemic anticoagulant shift. Such lack of correlation between anticoagulant and antithrombotic effects has been demonstrated earlier with this model. A bolus of standard heparin, which produced a heavy and long-standing anticoagulation, was clearly inferior in antithrombotic potency to a bolus of the specific thrombin inhibitor hirudin, whose anticoagulant response was considerably milder and more transient (51). Together, these studies indicate that conventional parameters of plasma anticoagulation are not reliable in monitoring the antithrombotic effect of a given agent, and that the impact of an antithrombotic regimen seems to reside in its ability to produce a site-directed action by means of favorable kinetics, either as a cofactorassisted or a direct action.

Protein S alone did not exhibit any antithrombotic or anticoagulant properties in this model, seemingly discordant with the findings of Heeb et al. showing an APC-independent anticoagulant effect of protein $S$ in an in vitro system (33). Apart from species differences and the general observation that in vitro data do not necessarily have in vivo correlates, a possible anticoagulant effect of protein $\mathrm{S}$ may not be powerful enough to manifest itself as an antithrombotic effect in a hypertraumatic model.

The infusion of C4BP resulted in a distinct drop in platelet count, for which we have no explanation. The endotoxin levels in the protein preparations were far below those that trigger disseminated intravascular coagulation with platelet consump- 
tion in rabbits $(52,53)$. Similar effects on platelets by C4BP infusion in baboons have been described by Taylor et al., but this was associated with severe inflammatory challenge (30). In their experimental setting, a sublethal inflammatory challenge with $E$. coli infusion was converted into a lethal one by complexing baboon protein $\mathrm{S}$ with human $\mathrm{C} 4 \mathrm{BP}$, a course that was not altered even when the coagulopathic response was selectively blocked by anticoagulation of the animals. These findings suggest that protein $\mathrm{S}$ may have a key function in modulating inflammatory responses.

When potentiated by its specific cofactor protein S, APC provides an effective site-directed antithrombotic effect without significant systemic anticoagulation or hemorrhagic side effects. Extrapolating these data to the clinical setting of treating human thrombotic disease, human APC, possibly supplemented by protein S, might have potential as an antithrombotic agent.

\section{Acknowledgments}

We gratefully acknowledge Ulf Strömberg, Ph.D. (Department of Occupational and Environmental Medicine, Lund University), for help with statistical analyses, and Mrs. Bergisa Hildebrand, Mrs. Lise Borge, and the staff at the Department for Coagulation Disorders, Malmö General Hospital, for skillful technical assistance. Tore Sveälv, Chromogenix $\mathrm{AB}$, Mölndal, Sweden, is gratefully acknowledged for measurement of endotoxin levels.

This work was supported by the Swedish Medical Council (grant numbers 07143 and 10827), and by grants from the King Gustaf V's 80th Birthday Trust, the King Gustav V and Queen Victoria Trust, the Magnus Bergwall Trust, the Albert Påhlsson Trust, the Johan Kock Trust, Malmö General Hospital research funds, Anna-Lisa and Sven Eric Lundgrens Trust, and the Crafoord Trust.

\section{References}

1. Dahlbäck, B., and J. Stenflo. 1994. A natural anticoagulant pathway. Biochemistry and physiology of proteins $\mathrm{C}, \mathrm{S}, \mathrm{C} 4 \mathrm{~b}$-binding protein and thrombomodulin. In Haemostasis and Thrombosis. Third edition. A. L. Bloom, C. D. Forbes, D. P. Thomas, and E. G. D. Tuddenham, editors. Churchill Livingstone, London. 671-698.

2. Dahlbäck, B. 1991. Protein S and C4b-binding protein: components involved in the regulation of the protein $\mathrm{C}$ anticoagulant system. Thromb. Haemostasis. 66:49-61.

3. Comp, P. C., and C. T. Esmon. 1984. Recurrent thromboembolism in patients with a partial deficiency of protein S. N. Engl. J. Med. 311:1525-1528.

4. Bertina, R. M., A. van Wijngaarden, J. Reinalda-Poot, S. R. Poort, and V. J. Bom. 1985. Determination of plasma protein S-the protein cofactor of activated protein C. Thromb. Haemostasis. 53:268-272.

5. Dahlbäck, B. 1986. Inhibition of protein Ca cofactor function of human and bovine protein S by C4b-binding protein. J. Biol. Chem. 261:12022-12027.

6. He, X., and B. Dahlbäck. 1993. Molecular cloning, expression and characterization of rabbit vitamin K-dependent protein S. Eur. J. Biochem. 217:857865.

7. He, X., and B. Dahlbäck. 1994. Rabbit plasma, unlike its human counterpart, contains no complex between protein $\mathrm{S}$ and $\mathrm{C} 4 \mathrm{~b}$-binding protein. Thromb. Haemostasis. 71:446-451.

8. Dahlbäck, B., M. Carlsson, and P. Svensson. 1993. Familial thrombophilia due to a previously unrecognized mechanism characterized by poor response to activated protein C: prediction of a cofactor to activated protein C. Proc. Natl. Acad. Sci. USA. 90:1004-1008.

9. Dahlbäck, B., and B. Hildebrand. 1994. Inherited resistance to activated protein $\mathrm{C}$ is corrected by anticoagulant cofactor activity found to be a property of factor V. Proc. Natl. Acad. Sci. USA. 91:1396-1400.

10. Shen, L., and B. Dahlbäck. 1994. Factor V and protein $S$ as synergistic cofactors to activated protein $\mathrm{C}$ in degradation of factor VIIIa. J. Biol. Chem. 269:18735-18738.

11. Marlar, R. A., and A. Neumann. 1990. Neonatal purpura fulminans due to homozygous protein $\mathrm{C}$ or protein $\mathrm{S}$ deficiency. Semin. Thromb. Hemostasis. 16:299-309.

12. Broekmans, A. W., J. J. Veltkamp, and R. M. Bertina. 1983. Congential protein C deficiency and venous thromboembolism. N. Engl. J. Med. 309:340344.

13. Svensson, P. J., and B. Dahlbäck. 1994. Resistance to activated protein C as a basis for venous thrombosis. N. Engl. J. Med. 330:517-522.

14. Griffin, J. H., B. Evatt, C. Wideman, and J. A. Fernández. 1993. Anticoagulant protein $\mathrm{C}$ pathway defective in majority of thrombophilic patients. Blood. 82:1989-1993.

15. Koster, T., T. R. Rosendal, H. de Ronde, E. Briët, J. P. Vandenbroucke, and R. M. Bertina. 1993. Venous thrombosis due to poor anticoagulant response to activated protein C: Leiden thrombophilia study. Lancet. 342:1503-1506.

16. Faioni, E. M., F. Franchi, D. Asti, E. Sacchi, F. Bernardi, and P. M Mannucci. 1993. Resistance to activated protein C in nine thrombophilic families: interference in a protein $\mathrm{S}$ functional assay. Thromb. Haemostasis. 70:1067-1071.

17. Bertina, R. M., B. P. C. Koeleman, T. Koster, F. R. Rosendaal, R. J. Dirven, H. de Ronde, P. A. van der Velden, and P. H. Reitsma. 1994. Mutation in blood coagulation factor $\mathrm{V}$ associated with resistance to activated protein $\mathrm{C}$. Nature (Lond.). 369:64-67.

18. Greengard, J. S., X. Sun, X. Xu, J. A. Fernandez, J. H. Griffin, and B. Evatt. 1994. Activated protein C resistance caused by Arg506Gln mutation in factor Va. Lancet. 343:1362-1363.

19. Voorberg, J., J. Roelse, R. Koopman, H. Büller, F. Berends, J. W. Tencate, K. Mertens, and J. A. van Mourik. 1994. Association of idiopathic thromboembolism with single point mutation at Arg506 of factor V. Lancet. 343:1535-1536.

20. Zöller, B., and B. Dahlbäck. 1994. Linkage between inherited resistance to activated protein $\mathrm{C}$ and factor $\mathrm{V}$ gene mutation in venous thrombosis. Lancet. 343:1536-1538.

21. Taylor, F. B., A. Chang, C. T. Esmon, A. D'Angelo, S. Vigano-D'Angelo, and K. E. Blick. 1987. Protein C prevents the coagulopathic and lethal effects of Escherichia coli infusion in the baboon. J. Clin. Invest. 79:918-925.

22. Emerick, S. C., N. U. Bang, S. B. Yan, G. L. Long, C. S. Harms, C. Huss, C. A. Marks, L. E. Mattler, P. C. Comp, N. B. Esmon, and C. T. Esmon. 1985 Antithrombotic properties of activated human protein C. Blood. 66(Suppl. 1):349a. (Abstr.)

23. Smirnov, M. D., M. V. Pyzh, D. V. Borovikov, A. N. Atorozhilova, A. B. Dobrovolski, V. L. Golubych, and N. A. N. A. Gratsiansky. 1990. Low doses of activated protein $\mathrm{C}$ delay arterial thrombosis in rats. Thromb. Res. 57:645-650.

24. Araki, H., K. Nishi, N. Ishihara, and K. Okajima. 1991. Inhibitory effects of activated protein $\mathrm{C}$ and heparin on thrombotic arterial occlusion in rat mesenteric arteries. Thromb. Res. 62:209-216.

25. Gruber, A., J. H. Griffin, L. A. Harker, and S. R. Hanson. 1989. Inhibition of platelet-dependent thrombus formation by human activated protein $\mathrm{C}$ in a primate model. Blood. 73:639-642.

26. Gruber, A., S. R. Hanson, A. B. Kelly, B. S. Yan, N. Bang, J. H. Griffin, and L. A. Harker. 1990. Inhibition of thrombus formation by activated recombinant protein $\mathrm{C}$ in a primate model of arterial thrombosis. Circulation. 82:578585.

27. Hanson, S. R., J. H. Griffin, L. A. Harker, A. B. Kelly, C. T. Esmon, and A. Gruber. 1993. Antithrombotic effects of thrombin-induced activation of endogenous protein C in primates. J. Clin. Invest. 92:2003-2012.

28. Emekli, N. B., and O. N. Ulutin. 1980. The protective effect of autoprothrombin II-anticoagulant on experimental DIC formed animals. Haematolog ica. 65:644-651.

29. Arnljots, B., D. Bergqvist, and B. Dahlbäck. 1994. Inhibition of microarterial thrombosis by activated protein $\mathrm{C}$ in a rabbit model. Thromb. Haemostasis. 72:415-420.

30. Taylor, F. B., A. Chang, T. Ferrel, T. Mather, R. Catlett, K. Blick, and C. T. Esmon. 1991. C4b-binding protein exacerbates the host response to Escherichia coli. Blood. 78:357-363.

31. Tans, G., J. Rosing, M. C. L. G. D. Thomassen, M. J. Heeb, R. F. A Zwaal, and J. H. Griffin. 1991. Comparison of anticoagulant and procoagulant activities of stimulated platelets and platelet-derived microparticles. Blood. 77:2641-2648.

32. Solymoss, S., M. M. Tucker, and P. B. Tracy. 1988. Kinetics of inactivation of membrane-bound factor V by activated protein C. J. Biol. Chem. 263:1488414890.

33. Heeb, M. J., R. M. Mesters, G. Tans, J. Rosing, and J. H. Griffin. 1993 Binding of protein $\mathrm{S}$ to factor $\mathrm{Va}$ associated with inhibition of prothrombinase that is independent of activated protein C. J. Biol. Chem. 268:2872-2877.

34. Regan, L. M., B. J. Lamphear, F. J. Walker, and P. J. Fay. 1994. Factor IXa protects factor VIIIa from activated protein C: factor IXa inhibits activated protein C-catalyzed cleavage of factor VIIIa at Arg562. J. Biol. Chem. 269:94459452.

35. Walker, F. J. 1981. Regulation of activated protein $C$ by protein $S$. The role of phospholipid in factor Va inactivation. J. Biol. Chem. 256:11128-11131.

36. Walker, F. J. 1984. Protein S and the regulation of activated protein C. Semin. Thromb. Hemostasis. 10:131-138.

37. Walker, F. J. 1981. Regulation of bovine activated protein C by protein 
S: the role of the cofactor protein in species specificity. Thromb. Res. 22:321327.

38. Arnljots, B., P. Dougan, J. Wieslander, L. Salemark, and D. Bergqvist. 1994. Platelet accumulation and thrombus formation after microarterial injury: an experimental study in rabbits. Scand. J. Plast. Reconstr. Surg. Hand Surg. 28:167175.

39. Acland, R. D. 1980. Microsurgery Practice Manual. Mosby, St Louis. p. 58.

40. Stenflo, J. 1976. A new vitamin K-dependent protein. Purification from bovine plasma and preliminary characterization. J. Biol. Chem. 251:355-363.

41. Stenflo, J., and M. Jönsson. 1979. Protein S, a new vitamin K-dependent protein from bovine plasma. FEBS (Fed. Eur. Biochem. Soc.) Lett. 101:377-381.

42. Hillarp, A., and B. Dahlbäck. 1988. Novel subunit in C4b-binding protein required for protein S binding. J. Biol. Chem. 263:12759-12764.

43. Dahlbäck, B., B. Hildebrand, and J. Malm. 1990. Characterization of functionally important domains in human vitamin $\mathrm{K}$-dependent protein $\mathbf{S}$ using monoclonal antibodies. J. Biol. Chem. 265:8127-8135.

44. Lehmann, E. L. 1975. Nonparametrics: Statistical Methods Based on Ranks. Mc Graw-Hill Inc., New York. 232-235.

45. Wieslander, J., P. Dougan, U. Stjernquist, and C. vMecklenburg. 1986. Effect of Dextran 70 and saline on thrombus formation following arteriotomy and intimectomy in small arteries. Microsurgery. 7:168-177.

46. Wieslander, J., and P. Dougan. 1990. Washout of vessels with heparin does not improve patency following a severe microarterial trauma. Ann. Plast. Surg. 24:216-222.
47. Salemark, L. 1991. Antithrombotic therapy in microvascular surgery. Experimental studies of the antithrombotic and antiplatelet effects of dextran 40, prostacyclin, and acetylsalicylic acid. Ph.D. thesis. University of Lund, Malmö, Sweden. 136 pp.

48. Arnljots, B., J. Wieslander, P. Dougan, and L. Salemark. 1992. Prevention of microvascular thrombosis with low dose tissue plasminogen activator. Plast. Reconstr. Surg. 90:281-288.

49. Arnljots, B., P. Dougan, L. Salemark, and D. Bergqvist. 1994. Effects of streptokinase and urokinase on microvascular thrombus formation and haemostasis. Scand. J. Plast. Reconstr. Surg. Hand. Surg. 28:9-13.

50. Zhang, B. 1993. Antithrombotic therapy in small arteries and veins. Experimental studies of trauma models, heparin, LMWH, Dextran 70 and tranexamic acid. Ph.D. thesis. University of Lund, Malmö, Sweden. 148 pp.

51. Arnljots, B., and D. Bergqvist. 1995. Inhibition of heparin-resistant microarterial thrombosis by recombinant hirudin-a specific thrombin inhibitor. Plast. Reconstr. Surg. 95:894-900.

52. Warr, T. A., L. V. M. Rao, and S. I. Rapaport. 1990. Disseminated intravascular coagulation in rabbits induced by administration of endotoxin or tissue factor: effect of anti-tissue-factor antibodies and measurement of plasma extrinsic pathway inhibitor activity. Blood. 75:1481-1489.

53. Bregengård, C., O. Nordfang, P. Wildgoose, U. Hedner, and V. Diness 1993. The effect of two-domain tissue factor pathway inhibitor on endotoxininduced disseminated intravascular coagulation in rabbits. Blood Coagul. \& Fibrinolysis. 4:699-706. 